\title{
Teaching-learning methodologies from the perspective of nursing students
}

\author{
Metodologias de ensino-aprendizagem sob a perspectiva de discentes de enfermagem
}

Rafaella Queiroga Souto ${ }^{1}$, Francisca Marcia Pereira Linhares², Maria Isabelly de Melo Canêjo ${ }^{2}$, Francis Solange Vieira Tourinho ${ }^{3}$, Renata Cavalcanti Cordeiro ${ }^{4}$, Pierre Pluye $^{5}$

Objective: to evaluate the teaching-learning methodologies adopted by teachers of a Nursing course from the perspective of students. Methods: research with mixed methods of the convergent type. This is an excerpt of a comprehensive project of evaluation a program, using the Context, Input, Process, and Product evaluation model. Quantitative data (cross-sectional study with secondary data) and qualitative data were collected concomitantly and then triangulated. Results: regarding the teaching methodologies adopted by teachers, the participating students reported greater use of expository and dialogic classes, 161 (67.6\%), among teachers of the basic subjects; and non-dialogic expository classes, 226 (92.6\%), by teachers of specific subjects of the nursing area. Traditional teaching and traditional assessment methodologies predominated in all courses. Conclusion: the participating students considered predominantly traditional methodologies and wanted to experience active methods, highlighting the need for interdisciplinarity and greater teaching-service-community integration.

Descriptors: Faculty; Nursing; Methodology; Nursing Evaluation Research.

Objetivo: avaliar as metodologias de ensino-aprendizagem adotadas por docentes de um curso de Enfermagem, sob a perspectiva discente. Métodos: pesquisa com métodos mistos do tipo convergente. Recorte de projeto amplo de avaliação de programa, com uso do modelo Contexto, Insumos, Processo e Produto. Dados quantitativos (estudo transversal com dados secundários) e qualitativos coletados concomitantes e, posteriormente, triangulados. Resultados: sobre as metodologias de ensino adotadas por docentes, os discentes participantes referiram maior utilização de aulas expositivas e dialogadas, 161 (67,6\%), entre professores das disciplinas básicas; e de aulas expositivas e não dialogadas, 226 (92,6\%), por docentes de disciplinas específicas da enfermagem. Em todas as disciplinas, predominaram metodologias tradicionais de ensino e avaliação. Conclusão: os discentes participantes consideraram as metodologias predominantemente tradicionais e desejaram vivenciar métodos ativos, destacando a necessidade da interdisciplinaridade e maior integração ensino-serviço-comunidade.

Descritores: Docentes; Enfermagem; Metodologia; Pesquisa em Avaliação de Enfermagem.

\footnotetext{
${ }^{1}$ Universidade Federal da Paraíba. João Pessoa, PB, Brazil.

${ }^{2}$ Universidade Federal de Pernambuco. Recife, PE, Brazil.

${ }^{3}$ Universidade Federal de Santa Catarina. Florianópolis, SC, Brazil.

${ }^{4}$ Faculdade de Ciências Médicas de Campina Grande. Campina Grande, PB, Brazil.

${ }^{5}$ McGill University. Montreal, QC, Canadá. 


\section{Introduction}

Nursing, as a science, has undergone significant transformations over the years, given that the purely charitable attribution of the profession has given way to a scientific training based on the Brazilian political, economic and social model, being entirely linked to the principles and guidelines of the Unified Health System.

In Brazil, the profession emerged at the beginning of the 20th century, based on the public health policy of the Carlos Chagas Reform, when first nursing school, the Anna Nery Nursing School, was created in 1923, in Rio de Janeiro. However, training had a dichotomy, insofar as the theory worked in the preventive perspective, while practical teaching was carried out exclusively at the hospital level ${ }^{(1-2)}$.

In contemporary reality, there is a premise that most of the undergraduate courses have curricular matrices that are distant from the Brazilian social reality, and they work through vertical and rigid methodologies that are not attractive from the students' point of view ${ }^{(3-4)}$.

The current situation is in line with the assumptions of the Law of Guidelines and Bases of National Education, through professional training based on the effective construction of critical and reflexive thinking, through the development of skills related to: health care, decision-making, communication, leadership, administration and management, as well as continuing education ${ }^{(5)}$.

Based on these assumptions, the transition from traditional teaching to teaching based on active and innovative learning methodologies is imperative. The latter methodologies value the problematization and are intrinsically linked to situations of social reality, according to Freiri's proposal, of a learning process carried out by active and participating subjects, who seek to construct critical knowledge and focus on the search for autonomy ${ }^{(6)}$.

However, banking education, which limits the leadership capacity and management of care, is wi- dely used because of the difficulty of students to accept methods of knowledge construction that stimulate criticality and autonomy, due to the convenience of receiving knowledge through simple transference from teachers, as well as the difficulty of teachers to adhere to the use of active methodologies ${ }^{(7)}$. Thus, the process of training nursing students requires special attention, insofar as these professionals are essential for the development of the Unified Health System.

Given this context, this study aimed to evaluate the teaching-learning methodologies adopted by teachers of a nursing course from the perspective of students.

\section{Methods}

Research with mixed methods, consisting of a combination of quantitative and qualitative methods, of the convergent type, whose quantitative and qualitative data were collected concomitantly ${ }^{(8-9)}$. This study is part of a broad curricular evaluation proposal that is being conducted in stages. Each phase corresponds to the components of the Context, Input, Process, and Product evaluation model ${ }^{(10)}$, which has been used to provide a broad and detailed view of the current situation of the curriculum of the Nursing course of the Universidade Federal de Pernambuco.

The context corresponds to the profile, the satisfaction, the perception, among others, of the stakeholders/involved people. The input component refers to the physical and human structure of the institution, besides the documentary adequacy (national curricular guideline, pedagogical project of the course, courses program and contents). The process refers to the application of this documentation in practice. Finally, the product evaluates, mainly, the performance of the students, especially of graduates ${ }^{(10)}$.

The team is made up of teachers from the Structuring Teaching Nucleus and other interested parties. Students enrolled in the Nursing course of the Universidade Federal de Pernambuco, Recife campus, participated in the study. No exclusion criteria were used. 
The quantitative data collection instrument was prepared by the team, based on an evaluation protocol built and applied by the Structuring Teaching Nucleus in 2015. The dependent variables were the evaluation of the teaching methodologies, the evaluation of processes used by the teachers, and the teaching characteristics (ease of communication, ease of establishing relationships, general culture, and political and didactic experience). The independent variables were the social variables of the students (age, special needs, presence of computer with internet at home, residence with family members, development of artistic and/ or cultural activity, practice of physical activity, study of another language, family income, scholarship, paid job, graduation in another course, graduation in a technical course) and the variables related to the knowledge of the curriculum (access and knowledge about the pedagogical project of the course).

Data were analyzed using descriptive statistics (absolute frequency, relative frequency, mean, standard deviation, minimum and maximum) and inferential statistics, and were tabulated in the Statistical Package for the Social Sciences, version 21.0. Before typing, the protocols were checked by a data collection supervisor. As the variables had no normal distribution, non-parametric tests were used. For variables related to the teaching and social methodologies related to the student's knowledge of the curriculum, the Chi-square or Fisher's Exact tests were used when the boxes had values lower than five. The error accepted for the measurements corresponded to $\mathrm{p}<0.05$.

Qualitative data were collected through a focal group mediated by the coordinator of the nursing course at the time of the research who has experience with the data collection method. Seventeen students from different semesters of the course participated in this research. The students of the course were invited to participate through informal invitations sent by electronic addresses of the classes and a group of an international social network in which students of the course share. The focus group lasted an hour and 40 minutes. The discussion was recorded and the lines were transcribed and saved in a protected Microsoft Word ${ }^{\circledR}$ document. The questions that led the focus group were: With respect to the curriculum of the Nursing course of the Universidade Federal de Pernambuco, what do you consider to be its strong points? What are its limitations? What do you think could be improved?

Qualitative data analysis was carried out by means of reading and rereading the transcribed speeches in search for convergence or divergence with the quantitative data analyzed. For the present article, no classical technique of qualitative data analysis was used because the objective was to seek in the statements aspects that would confirm or refute the information built upon the analysis of the quantitative data $^{(8-9)}$.

Although the questions were not addressed to the topic "teaching-learning methodologies", the contents of the evaluation of teaching methodologies that were triangulated to the quantitative answers emerged from the speeches. Data triangulation was the alternative analysis of quantitative and qualitative data, widely used in research with mixed methods of the convergent type ${ }^{(8-9)}$.

The study respected the ethical aspects involving human beings, as recommended by the National Health Council, by Resolution 466/2012, being approved under protocol no 54696416.5.0000.5208.

\section{Results}

The mean age of the participants was 21.57 years [standard deviation (SD) $=3.45$ ], with a minimum age of 17 and a maximum of 45 years. Most of the participants had no special needs, 233 (96.3\%); had a computer with internet at home, 237 (97.5\%); lived with relatives, 223 (91.0\%); did not develop any artistic and/or cultural activity, 218 (90.8\%); did not practice any physical activity, 182 (75.5\%); and had not studied any other language, 187 (76.6\%).

As for family income, 93 (38.1\%) received between two and five minimum wages, 66 (27.0\%) re- 
ceived one to two minimum wages, and $36(14.8 \%)$ received between five and 10 minimum wages; 20 $(8.2 \%)$ received up to one minimum wage and/or could not provide this information. Only seven (2.9\%) received between 10 and 30 minimum wages and two $(0.8 \%)$ more than 30 minimum wages.

Table 1 shows the distribution of the variables related to the evaluation of teaching methodologies by the participating students and the evaluation adopted by the teachers of the studied institution. It was observed that expository and dialogic classes, 161 (67.6\%), and laboratory practices, 92 (38.5\%), were widely used by teachers of basic subjects, and that expositive and non-dialogued classes, 226 (92.6\%), while expositive and dialogued classes were the most used among the methodologies adopted by the professors of specific subjects of Nursing.

When analyzing the methodologies used by the teachers of the studied institution, triangulated with the responses of the focus group, it was observed that the qualitative perception was coherent with the quantitative answers, according to Figure 1.

Table 1 - Description of the teaching methodologies adopted by teachers of the studied institution

\begin{tabular}{lcccccc}
\hline \multirow{2}{*}{ Variables } & \multicolumn{3}{c}{ Basic Subjects } & \multicolumn{3}{c}{ Specific Subjects } \\
\cline { 2 - 6 } & Yes & No & Total & Yes & No & Total \\
\cline { 2 - 7 } & $\mathbf{n}(\%)$ & $\mathbf{n ~ ( \% )}$ & $\mathbf{n ~ ( \% )}$ & $\mathbf{n ~ ( \% )}$ & $\mathbf{n ( \% )}$ & $\mathbf{n}(\%)$ \\
\hline Expositive non-dialogued class & $60(25.1)$ & $17(74.9)$ & $239(100.0)$ & $18(7.4)$ & $226(92.6)$ & $244(100.0)$ \\
Expositive dialogued class & $161(67.6)$ & $77(32.4)$ & $238(100.0)$ & $214(87.3)$ & $31(12.7)$ & $245(100.0)$ \\
Practical laboratory class & $92(38.5)$ & $147(61.5)$ & $239(100.0)$ & $44(18)$ & $201(82)$ & $245(100.0)$ \\
Technical visit & $5(2.1)$ & $234(97.9)$ & $239(100.0)$ & $42(17.1)$ & $203(82.9)$ & $245(100.0)$ \\
Clinical simulation & $5(2.1)$ & $234(97.9)$ & $239(100.0)$ & $35(14.5)$ & $210(85.7)$ & $245(100.0)$ \\
Reading and discussion of texts & $14(5.9)$ & $225(94.1)$ & $239(100.0)$ & $76(31)$ & $169(69)$ & $245(100.0)$ \\
Seminars & $33(13.8)$ & $206(84.1)$ & $239(100.0)$ & $72(29.4)$ & $173(70.6)$ & $245(100.0)$ \\
Practical class with supervision in health services & - & - & - & $55(22.4)$ & $189(77.5)$ & $244(100.0)$ \\
\hline
\end{tabular}

\begin{tabular}{|c|c|c|}
\hline Quantitative data & Qualitative data & Triangulation \\
\hline Expositive dialogued class & $\begin{array}{l}\text { There was a course that was terrible. In the tenth semester I talked } \\
\text { with the manager nurse, and she gave me some things that we can } \\
\text { perceive, such as fragility, it is the difficulty of the interdisciplinarity } \\
\text { of the content of this course (D01). The lack of integration between } \\
\text { teachers in the planning of the courses, then how we=ill we want to do an } \\
\text { interdisciplinary content if we do not sit down to see what I'm working } \\
\text { on and what I can contribute so that we can work the contents in an } \\
\text { interdisciplinary way (D05). }\end{array}$ & $\begin{array}{l}\text { Predominant use of traditional } \\
\text { teaching methods; } \\
\text { Absence of interdisciplinarity of } \\
\text { the contents of the courses. }\end{array}$ \\
\hline $\begin{array}{l}\text { Practical class in laboratory } \\
\text { Clinical simulation } \\
\text { Technical visit } \\
\text { Practical class with supervi- } \\
\text { sion in health services }\end{array}$ & $\begin{array}{l}\text { Both the service and the university need to establish a stronger bond, I } \\
\text { think teaching-service integration is necessary (D02). } \\
\text { Our teacher assigned a homework to present as a seminar; so in the first } \\
\text { part of our traineeship, she went to the traineeship; she took one morning } \\
\text { to show us how it was; the only problem is that this should be shown in all } \\
\text { traineeships, but that is not the case (D07). }\end{array}$ & $\begin{array}{l}\text { Lack of integration between edu- } \\
\text { cation and health services; } \\
\text { Successful interaction between } \\
\text { theory and practice. }\end{array}$ \\
\hline $\begin{array}{l}\text { Reading and discussion of } \\
\text { texts } \\
\text { Seminars Courses }\end{array}$ & $\begin{array}{l}\text { I used to study ethics, I would study nursing legislation, code of ethics, } \\
\text { but the way he brings it, in a dynamic way, the way I learned it (through } \\
\text { active methodologies), I think it was very valid (D09). }\end{array}$ & $\begin{array}{l}\text { Resistance about to active } \\
\text { methodologies is a reality on the } \\
\text { part of the students. }\end{array}$ \\
\hline
\end{tabular}

Figure 1 - Triangulation of the students' responses in the focal group before the quantitative instrument 
When questioned if they would like to experience some other form of teaching methodology, 155 (68.3\%) said yes and suggested some other options such as clinical simulation, dynamic activities and practical classes.

In relation to the forms of evaluation adopted by the teachers of the studied institution, the students mentioned written tests, 243 (99.2\%), and performance in practical activities, 134 (54.7\%), as the most prevalent forms. Other forms of evaluation used by teachers included seminars, $160(65.3 \%)$ and participation/attendance, 215 (87.8\%).

The teaching characteristics considered most important by the participating students were analyzed by means of a Likert-type scale in which the students assigned scores from one to ten for each item; zero corresponded to the minimum score and ten to the maximum score. Ease of communication was the best scored characteristic, with an average of 8.52 , followed by ease of establishment of relationships (7.63) and didactic skills (7.11). The characteristics considered less important were average general culture (3.88) and average political experience (2.06).

As shown in Table 2, significant associations were identified from the statistical point of view between the following variables: paid job and practical classes $(\mathrm{p}=0.019$, Confidence Interval $=1.279-9.997$ ) and reading and discussion of texts $(\mathrm{p}=0.046$; Confidence Interval $=0.988-7.215)$ and between the variable "has access to the Pedagogical Project of the Course" with the variables "technical visits" ( $p=0.044$, $\mathrm{CI}=0.947-5.052)$ and "reading and discussion of texts" ( $\mathrm{p}=0.008 ; \mathrm{CI}=1.194-4.307)$.

Among the association tests performed between the variables related to the forms of evaluation and to the social characteristics and knowledge of the Political Pedagogical Project of the Course by the students, the variables "scholarship holder" and "evaluation through participation/attendance "were significantly associated ( $p=0.023 ; \mathrm{CI}=0.187-0.902)$.

Table 2 - Relationship between variables related to the methodologies used by the teachers and their characteristics with the social variables and variables related to the knowledge of the Political Pedagogical Project of the course by the participating students

\begin{tabular}{|c|c|c|c|c|c|c|}
\hline \multirow{3}{*}{ Variables } & \multicolumn{6}{|c|}{ Teaching dependent variables } \\
\hline & \multicolumn{3}{|c|}{ Practical class } & \multicolumn{3}{|c|}{ Discussions } \\
\hline & $n(\%)$ & n(\%) & $\mathrm{p}(\mathrm{CI})^{*}$ & n(\%) & n(\%) & p (CI)* \\
\hline \multicolumn{7}{|c|}{ Scholarship holder } \\
\hline Yes & $15(6.2)$ & $29(12.0)$ & \multirow{2}{*}{$0.324(0.62-2.50)$} & $24(9.9)$ & $52(21.5)$ & \multirow{2}{*}{$0.428(0.61-1.98)$} \\
\hline No & $58(24.0)$ & $140(57.9)$ & & $49(20.2)$ & $117(48.3)$ & \\
\hline \multicolumn{7}{|c|}{ Other course } \\
\hline Yes & $1(0.4)$ & $43(17.6)$ & \multirow{2}{*}{$0.633(0.09-6.44)$} & $3(1.2)$ & $73(29.8)$ & \multirow{2}{*}{$0.376(0.37-7.76)$} \\
\hline No & $6(2.4)$ & $195(79.6)$ & & $4(1.6)$ & $165(67.3)$ & \\
\hline \multicolumn{7}{|c|}{ Technical course } \\
\hline Yes & $12(4.9)$ & $32(13.1)$ & \multirow{2}{*}{$0.100(0.83-3.79)$} & $32(13.1)$ & $137(55.9)$ & \multirow{2}{*}{$0.506(0.53-2.08)$} \\
\hline No & $35(14.3)$ & $166(67.8)$ & & $9(3.7)$ & $8(3.3)$ & \\
\hline \multicolumn{7}{|l|}{ Paid job } \\
\hline Yes & $7(2.9)$ & $10(4.1)$ & \multirow{2}{*}{0.019 (1.28-9.99) } & $9(3.7)$ & $8(3.3)$ & \multirow{2}{*}{$0.046(0.98-7.21)$} \\
\hline No & $37(15.2)$ & $189(77.8)$ & & $67(27.6)$ & $159(65.4)$ & \\
\hline \multicolumn{7}{|c|}{$\begin{array}{l}\text { Access to the Political Pedagogical } \\
\text { Project of the Course }\end{array}$} \\
\hline Yes & $31(13.4)$ & $11(4.8)$ & \multirow{2}{*}{$0.099(0.82-3.66)$} & $52(22.5)$ & $16(6.9)$ & \multirow{2}{*}{$0.008(1.19-4.31)$} \\
\hline No & $117(50.6)$ & $72(31.2)$ & & $96(41.6)$ & $67(29.0)$ & \\
\hline
\end{tabular}




\section{Discussion}

The study presented a limitation regarding the method because in cross-sectional researches, the associations and the description of data are presented within a specific historical period, restricting the interpretations of the studied phenomena. No restrictions related to the integration of quantitative and qualitative data were identified.

The results showed that Nursing education in Brazil is marked by banking education and interdisciplinarity is not effective among the courses of the curricular matrix. The students' speeches pointed to a lack of interaction between the courses, as well as a poor applicability of the theory to the nurses' performance in the different health services. These qualitative data were in line with the quantitative findings that identified teaching strategies used in isolation, with emphasis on expositive and dialogued classes, as well as on expositive and non-dialogued classes.

Banking education can cause significant damage to students, insofar as they are trained. The students reproduce what is transmitted in the classroom without having consolidated political and ethical principles of inclusion and justice, thus implying great difficulties to be inserted into the reality of the Brazilian health system. In order to overcome this teaching model and to catch up with governmental measures that have restructured the training of health professionals in accordance to the reality of excellence of teaching as a practice, it is necessary to train and prepare teachers on teaching methodologies and didactic-pedagogical specificities, considering that the transformation of education beyond know-how produces the possibility of transformative teaching ${ }^{(11)}$.

It is worth emphasizing that the effective construction of knowledge should not be a reality only of the basic courses, but also of specific components of the curricula because the preparation of nurses occurs through the sedimentation of basic knowledge and is consolidated with the specific knowledge. In this study, it was identified that $67.6 \%$ of classes were expositive and dialogued, a fact that disregards the current need for teaching, considering that when students are asked and encouraged to build their own knowledge with guidance and the incentive of teachers, knowledge is grounded in a deeper and more lasting way.

This context reveals that nursing students consider anatomy as an indispensable discipline for knowledge, because it is fundamental for the accomplishment of care in an effective way. However, they considered it complex and full of obstacles for the construction of learning due to the fact that the subjects are not learned but rather memorized, causing discouragement and a sense of impotence on the part of the students. This reality can be applied to other courses of the basic education of health courses, evidencing therefore the need for spaces of exchange and collective construction also of the basic courses, so that the training process happens in a proper and effective way ${ }^{(12)}$.

The absence of interdisciplinarity and lack of dialogue between teachers regarding the planning of courses and their approximation with the professional reality were also identified. In order to meet these goals, the teachers must raise awareness among students regarding class planning with a view to strengthening and valuing science as a foundation for the nursing professional training and performance ${ }^{(13)}$.

The fact of working as a team represents an interdisciplinary element of humanization in the Nursing course, being an effective articulation between teaching institutions and health practice scenarios, considering that practical experiences are significant for the articulation between what is learned in the classroom and what is effectively experienced in practice in favor of the Unified Health System ${ }^{(14)}$.

Thus, the use of active teaching methodologies is an urgent need for Brazilian education, as well as for health courses, because the profile of the academic 
aspect has changed and teaching must walk hand in hand with this change, investing in the protagonism and active and collective construction of knowledge about health.

In this perspective, digital educational technologies are one of the innumerable alternatives of teaching the nursing competences and skills having the students as protagonists of the knowledge, through critical-reflexive thought and in an active way, to the extent that this dynamic form of teaching contributes to obtaining theoretical references and allowing the break with traditional teaching that simply shows and repeats procedures. In this context, online simulations, the use of virtual learning environments and other digital didactic materials can be mentioned. These resources can contribute to the development of skills and knowledge capable of mobilizing attitudes of troubleshooting ${ }^{(15)}$.

Meta-analysis conducted with the inclusion of 12 studies aimed at comparing Problem Based Learning with the traditional teaching method demonstrated the effectiveness of this methodology to increase the critical thinking of students ${ }^{(16)}$. Problem Based Learning is thus a viable alternative to the teaching traditionally centered on the teacher and the transmission of knowledge in nursing undergraduate courses.

A positive aspect identified in this study was the successful interaction between theory and practice. This reality is recommended by the National Curricular Guidelines and, from the quantitative and qualitative perspective of students, it is present in the routine of the Nursing course studied.

\section{Conclusion}

The Participating students considered predominantly traditional methodologies and showed interest in experiencing active methods, highlighting the need for interdisciplinarity and greater teaching-service-community integration.

\section{Collaborations}

Queiroga RS and Linhares FMP contributed in the design of the project and in the relevant critical review of intellectual content. Canêjo MIM and Tourinho FSV contributed in the analysis and interpretation of the data and writing of the article. Cordeiro RC and Pluye P collaborated in the relevant critical review of intellectual content and approved the final version to be published.

\section{References}

1. Oliveira MCM. A formação do profissional enfermeiro, no contexto das reformas de ensino, no Brasil. Grifos. 2014; 23(36/37):135-42. doi: http:// dx.doi.org/10.22295/grifos.v23i36/37.2784

2. Melo CSB, Miranda R, Cirino SD, Campos RHF. A Psicologia na formação de enfermeiros. Estud Pesqui Psicol [Internet]. 2014 [citado 2018 mar. 27]; 14(1):337-54. Disponível em: http:// pepsic.bvsalud.org/scielo.php?script $=\mathrm{sci}_{-}$ arttext\&pid=S1808-42812014000100019

3. Paim AS, Iappe NT, Rocha DLB. Metodologias de ensino utilizadas por docentes do curso de enfermagem: enfoque na metodologia problematizadora. Enferm Glob [Internet]. 2015 [citado 2018 mar. 24]; 14(37):153-69. Disponível em: http://scielo. isciii.es/pdf/eg/v14n37/docencia2.pdf

4. Machado $\mathrm{MH}$, Wermelinger $\mathrm{M}$, Vieira $\mathrm{M}$, Oliveira E, Lemos W, Aguiar Filho W, et al. Aspectos gerais da formação da enfermagem: o perfil da formação dos enfermeiros, técnicos e auxiliares. Enferm Foco. 2016; 7(esp):15-34. doi: https://doi. org/10.21675/2357-707X.2016.v7.nESP.687

5. Ministério da Educação (BR). Conselho Nacional de Educação, Câmara de Educação Superior. Resolução CNE/CES no 3 de 7 de novembro de 2001: Diretrizes Curriculares Nacionais do Curso de Graduação em Enfermagem. Brasília: Ministério da Educação; 2001.

6. Simon E, Jezine E, Vasconcelos EM, Ribeiro KSQS. Metodologias ativas de ensino-aprendizagem e educação popular: encontros e desencontros no contexto da formação dos profissionais de saúde. Interface. 2014; 18(2):1355-64. doi: http:// dx.doi.org/10.1590/1807-57622013.0477 
7. Amestoy SC, Backes VMS, Thofehrn MB, Martini JG, Meirelles BHS, Trindade LL. Nurses' perception of the teaching-learning process of leadership. Texto Contexto Enferm. 2013; 22(2):46875. doi: http://dx.doi.org/10.1590/S010407072013000200024

8. Creswell, JW, Clark VLP. Pesquisa de métodos mistos. Porto Alegre: Penso; 2013.

9. Santos JLG, Erdmann AL, Meirelles BHS, Lanzoni GMM, Cunha VP, Ross R. Integrating quantitative and qualitative data in mixed methods research. Texto Contexto Enferm. 2017; 6(2):e1590016. doi:http://dx.doi.org/10.1590/010407072017001590016

10. Bollela VR, Castro M. Avaliação de programas educacionais nas profissões da saúde: conceitos básicos. Medicina (Ribeirão Preto). 2014; 47(3):332-42. doi: http://dx.doi.org/10.11606/ issn.2176-7262.v47i3p333-342

11. Canever BP, Prado ML, Gomes DC, Jesus BH, Backes VMS. Naive world awareness in the pedagogical practice of healthcare professors. Texto Contexto Enferm. 2017; 26(2):e3340015. doi: http:// dx.doi.org/10.1590/0104-07072017003340015
12. Salbego C, Oliveira EMD, Silva MAR, Buganca PR. Percepções acadêmicas sobre o ensino e a aprendizagem em anatomia humana. Rev Bras Educ Med. 2015; 39(1):23-31. doi: http://dx.doi. org/10.1590/1981-52712015v39n1e00732014

13. Silva IR, Leite JL, Trevizan MA, Mendes IAC, Silva TP, Lins SMSB. Learning through research: from teaching science to the sphere of nursing care. Esc Anna Nery. 2017; 21(4):e20160329. doi: http:// dx.doi.org/10.1590/2177-9465-ean-2016-0329

14. Freitas FDS, Ferreira MA. Humanization knowledge of undergraduate nursing students. Rev Bras Enferm. 2016; 69(2):282-9. doi: ttp:// dx.doi.org/10.1590/0034-7167.2016690211i

15. Silveira MS, Cogo ALP. The contributions of digital technologies in the teaching of nursing skills: an integrative review. Rev Gaúcha Enferm. 2017; 24(2):e66204. doi: http://dx.doi. org/10.1590/1983-1447.2017.02.66204

16. Oliveira LB, Díaz LJR, Carbogim FC, Rodrigues ARB, Püschel VAA. Effectiveness of teaching strategies on the development of critical thinking in undergraduate nursing students: a metaanalysis. Rev Esc Enferm USP. 2016; 50(2):355364. doi: http://dx.doi.org/10.1590/S0080623420160000200023 